TECHNICAL TRANSACTIONS 11/2018

MECHANICS

DOI: $10.4467 / 2353737$ XCT.18.172.9428 SUBMISSION OF THE FINAL VERSION: 29/10/2018

Agata Dudek (D) orcid.org/0000-0001-9115-028X

dudek@wip.pcz.pl

Barbara Lisiecka (iD) orcid.org/0000-0002-0945-3423

Katarzyna Strzelczak (iD) orcid.org/0000-0002-5869-2324

Institute of Materials Engineering, Faculty of Production Engineering and Materials

Technology, Czestochowa University of Technology

\title{
ASSESSMENT OF THE QUALITY OF EPOXY COATING IN THE AUTOMOTIVE INDUSTRY
}

OCENA JAKOŚCI POWŁOKI EPOKSYDOWEJ W PRZEMYŚLE SAMOCHODOWYM

\begin{abstract}
Increasingly, many conventional and advanced automotive coatings applications demand materials with well-defined surface properties, fulfilling specific requirements and affecting automotive industrial development. The main assumption for the study was to analyze the microstructure and adhesion of epoxy powder coating on a steel substrate. The results of optical microscope metallographic, SEM/EDX, XRD analysis and adhesion test are presented.
\end{abstract}

Keywords: high strength low alloy (HSLA), S600 MC, epoxy powder coating, cross-cut test, ISO 2409:2013

\section{Streszczenie}

Coraz częściej, konwencjonalne i zaawansowane powłoki samochodowe wymagają materiałów o ściśle określonych właściwościach powierzchniowych, spełniających odpowiednie wymagania i wpływających na rozwój przemysłu samochodowego. Głównym założeniem badania była analiza mikrostruktury i przyczepności powłoki epoksydowej do podłoża stalowego. Uzyskano wyniki badań mikrostruktury za pomocą mikroskopii optycznej, skaningowej SEM/EDX, analizy XRD oraz przeprowadzono test adhezji powłoki.

Słowa kluczowe: wysokowytrzymała stal niskostopowa (HSLA), S600 MC, powłoka epoksydowa, test adhezji, ISO 2409:2013 


\section{Introduction}

Nowadays, the selection of suitable material is a key decision in the automotive industry. The whole process is loaded with requirements in the field of good fuel efficiency, reduction in the weight of the vehicle, consumer safety standards imposed by government and consumer demands. Material needs to possess such qualities as good weldability, mechanical properties, good formability, joinability, good corrosion resistance, functional properties (e.g. hardness and wear resistance), etc. Steels are one of the most popular and important structural materials in the world. Their use in the automotive industry is constantly growing. In order to achieve good balance of low cost, light weight and good mechanical properties, high strength low alloys (HSLA) [1-2] are increasingly used.

High strength low alloy steels (HSLA) are not considered as alloy steels in the normal sense because their main feature which is emphasized is mechanical properties and not their chemical composition. HSLA steels are more interesting than conventional carbon steel due to better mechanical properties and greater resistance to atmospheric corrosion. HSLA steels are mainly used in structural elements for the production of car parts, heavy-duty highway and off-road vehicles, mine and railroad cars and many others. The structural S600 MC steel is one of the types of HSLA steel used in the automotive industry. This steel is characterized by exhibit excellent cold forming, high strength, good welding performance, low-temperature brittle fracture strength, excellent dimension accuracy and surface properties in production. S600 MC steel can be used in many industries, such as car fabrication (e.g. automobile parts, suspension systems, truck chassis), machine parts manufacturing and construction industry. The high strength of these steels is designed to reduce weight and/or to increase payload [3-5].

In order to protect HSLA steel against different environmental factors, various types of coatings, paint and lacquers have been developed. The automotive coatings are exposed to UV rays, heat and humidity, falling objects, scratches, chipping (e.g. rock hits) and rust from salt or road deicers. Technology aims at the production of automotive coatings that will be characterized by durable surfaces, exceeding customers' expectations of appearance, maximizing efficiency, and meeting environmental regulations. The factors influencing the development and use of automotive coatings and coating technologies include, among others: corrosion protection, aesthetic characteristics, appearance quality, durability, cost and environmental requirements. The corrosion protection of cars [6-7] is the main problem in the automotive industry of economic importance.

As is well known, the protection of metal by coating consists in the creation of an insulating layer between a metal surface and corrosive environment. The durability of the coating depends on the barrier effect, adhesion and inhibiting features and the presence of an active pigment. Therefore, epoxy paint containing such a pigments is one of the most inexpensive and effective anti-corrosion coatings. Additionally, pigments give color and luster; they help to establish thickness to the coatings. The effective protection will be provided if the coating is sufficiently impermeable and evenly stretched without any break. Depending on the final application of the coated element, the coating thickness can amount to several hundreds of micrometers [8-9]. 
Currently, the use of an epoxy coating is an interesting solution to ensure reliability and long-term performance of coated automobile parts. Because the resins synthetic and crosslinkers form a film coating, they can be used to protect metallic engineering structures exposed by natural or artificial environment. Epoxy resins are used as aqueous dispersions or emulsions in anticorrosive paints for steel substrates. Due to their excellent chemical stability, good adhesion to metals substrates, resistance to moisture, different solvents and chemical species, the epoxy powder coating is a popular candidate for the development of corrosion resistant coating on a suspension system in the automotive industry [10-11].

\section{Material and Methods}

The specimens for the investigations were performed from S600 MC steel. The chemical composition of the $6600 \mathrm{MC}$ steel is presented in Table 1.

Table 1. Chemical composition of the S600 MC steel (\% wt.)

\begin{tabular}{|c|c|c|c|c|c|c|c|c|c|c|}
\hline $\mathbf{C}$ & $\mathbf{S i}$ & $\mathbf{M n}$ & $\mathbf{P}$ & $\mathbf{S}$ & $\mathbf{A l}$ & $\mathbf{N b}$ & $\mathbf{V}$ & $\mathbf{T i}$ & $\mathbf{M o}$ & $\mathbf{B}$ \\
\hline 0.120 & 0.500 & 1.900 & 0.025 & 0.015 & 0.015 & 0.090 & 0.200 & 0.220 & 0.500 & 0.005 \\
\hline
\end{tabular}

Before painting, the samples were degreased in acetone, left to dry at room temperature and washed with de-ionized water. The epoxy paint was applied using the powder coating method without any solvent. Two sets of samples were prepared in which the difference consisted in preparing the steel substrate. The steel in the first series of samples was polished in order to deprive the roughness surface. In the second series of samples, the steel had a rough surface to ensure better paint adhesion. After completion, the paint was allowed to cure for seven days. The epoxy powder coating thickness was measured after curing in order to ensure that the required values had been obtained $(50 \mu \mathrm{m})$.

The analysis of microstructure was carried out using the Olympus GX41 optical microscope. The analysis of morphology of the surface after powder paint was performed by using an Olympus SZ61 stereo microscope and a Jeol JSM-6610LV scanning microscope.

The identification of the phase composition of the epoxy powder coating was made using an X-ray diffractometer (Seifert $3003 \mathrm{~T}-\mathrm{T}$ ) with a cobalt lamp with characteristic radiation wavelength of $\lambda_{\text {cok } \alpha}=0.17902 \mathrm{~nm}$. Other parameters are presented in Table 2.

Table 2. X-ray diffractometer parameters

\begin{tabular}{|c|c|c|c|c|c|}
\cline { 2 - 6 } \multicolumn{1}{c|}{} & \multicolumn{5}{c|}{ Parameters } \\
\cline { 2 - 6 } & $\begin{array}{c}\text { Supply voltage } \\
\left(\boldsymbol{U}_{r}\right)\end{array}$ & $\begin{array}{c}\text { Current } \\
\text { intensity }\left(I_{r}\right)\end{array}$ & $\begin{array}{c}\text { Angle range } \\
(\mathbf{2} \boldsymbol{\theta})\end{array}$ & $\begin{array}{c}\text { Measurement } \\
\text { step }\end{array}$ & $\begin{array}{c}\text { Pulse } \\
\text { integration time } \\
\left(\boldsymbol{t}_{r}\right)\end{array}$ \\
\hline Ranges & $30 \div 40[\mathrm{kV}]$ & $30 \div 40[\mathrm{~mA}]$ & $10 \div 120^{\circ}$ & $0.1^{\circ}$ & $10[\mathrm{~s}]$ \\
\hline
\end{tabular}


In order to assess the quality of the epoxy powder coating, the adhesion test was made in accordance with the ISO 2409:2013 Paints and varnishes - Cross-cut test [12].

\section{Results and Discussion}

Figure 1 presents the microstructure obtained for specimens by an Olympus GX41 optical microscope. Taking into account the roughness surface of the steel substrate, Figure 1a shows better adhesion of the epoxy powder coating.

a)

b)
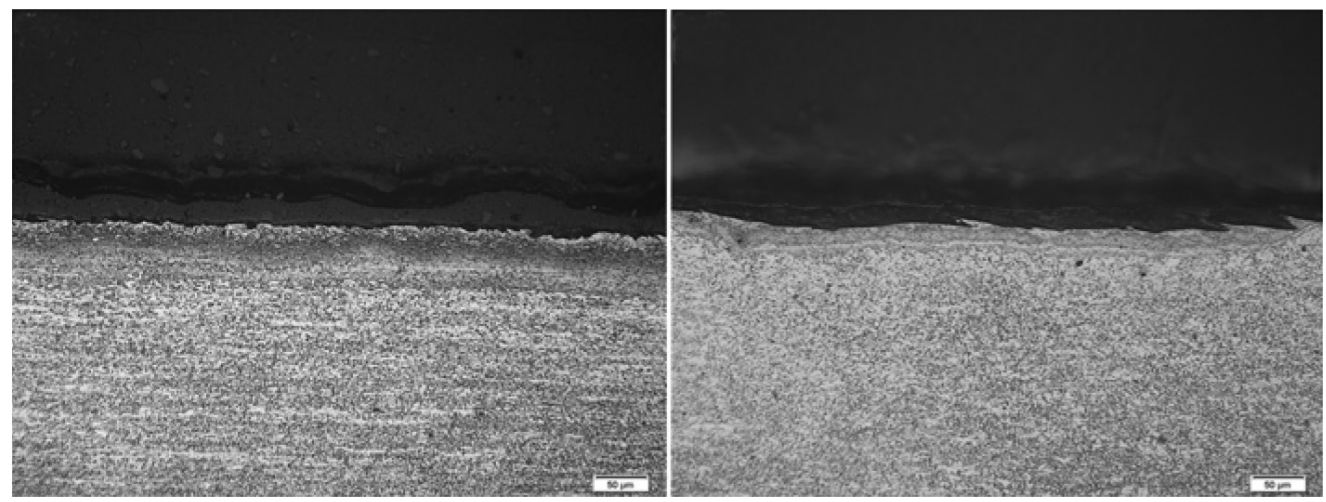

Fig. 1. Microstructure of epoxy powder coating with: a) good, b) poor quality of the steel substrate

Macroscopic examinations were used to evaluate the epoxy powder coating on the surface quality of the steel substrate. The analysis of the surface revealed numerous coating losses on the samples, whose steel substrate was completely smooth and did not have a rough surface. The quality of adhesion was confirmed by the adhesion test which was performed in accordance with the ISO 2409:2013. The samples were placed on a flat surface to prevent deformation during the test. On the surface, manual cutting was performed to gain a lattice pattern, following the specified procedure. The next step was to stick the adhesive tape on the surface and leave it for 5 minutes. After this time, the tape was removed. The obtained results were used to determine the resistance of the epoxy powder coating on the steel substrate. The samples with the epoxy powder coating on the rough surface of the steel substrate revealed a detachment of small flakes of the coating at the intersections of the cuts (below 5\%). Whereas, the samples with poor surface preparation showed a loss of coating greater than $15 \%$, but not greater than $35 \%$.

Figure 2 presents SEM microstructure images and EDS spectra in the epoxy powder coating identified by EDX analysis areas by a Jeol JSM-6610LV scanning microscope. The analysis of chemical composition of the epoxy powder coating surface is presented in Table 3.

The phase composition analysis for individual specimens revealed the presence of the crystallineamorphous crystallization, where the crystalline phase is carbon. The carbon crystallizes is a hexagonal cell of $\mathrm{P}$ (cell parameters: $\mathrm{a}=\mathrm{b}=0.89 \mathrm{~nm}, \mathrm{c}=0.14 \mathrm{~nm}, \alpha=\beta=90^{\circ}, \gamma=120^{\circ}$ ). 
a)

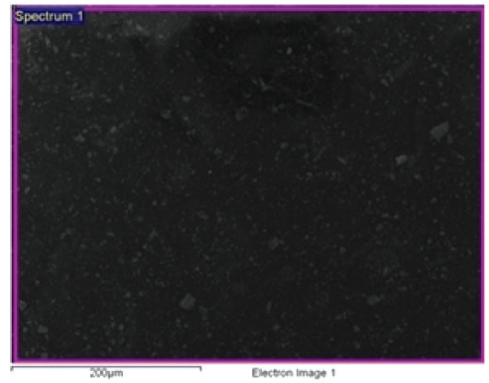

b)

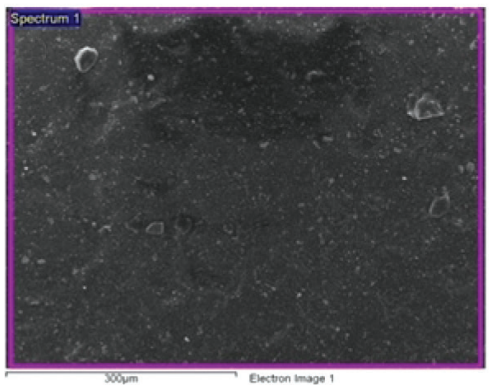

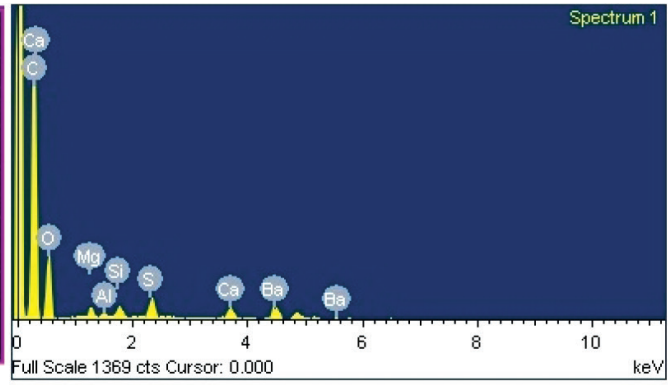

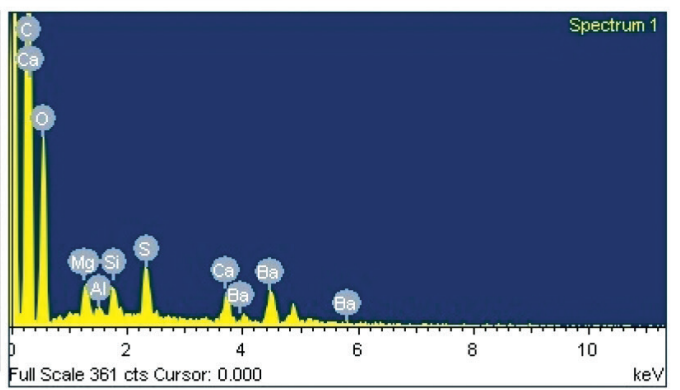

Fig. 1. Analysis of chemical composition of the surface in the epoxy powder coating (Spectrum 1) with: a) good, b) poor quality of the steel substrate

Table 3. EDX-analysis of chemical composition of the surface in the epoxy powder coating (location of the measurements is marked in Fig. 2)

\begin{tabular}{|c|c|c|c|c|c|c|c|c|c|}
\hline \multirow{4}{*}{\begin{tabular}{c} 
Epoxy powder \\
\multirow{2}{*}{$\begin{array}{c}\text { Quality of } \\
\text { the steel } \\
\text { substing }\end{array}$}
\end{tabular}} & \multicolumn{8}{|c|}{ Element [weight \%] } \\
\cline { 2 - 11 } & good & 66.12 & 23.90 & 0.78 & 0.09 & 0.59 & 1.56 & 1.07 & 5.89 \\
\cline { 2 - 11 } & poor & 68.33 & 23.65 & 0.70 & 0.14 & 0.38 & 1.26 & 1.05 & 4.49 \\
\cline { 2 - 11 }
\end{tabular}

Results of the analysis of phase composition of the epoxy powder coating are presented in Figure 3.

a)

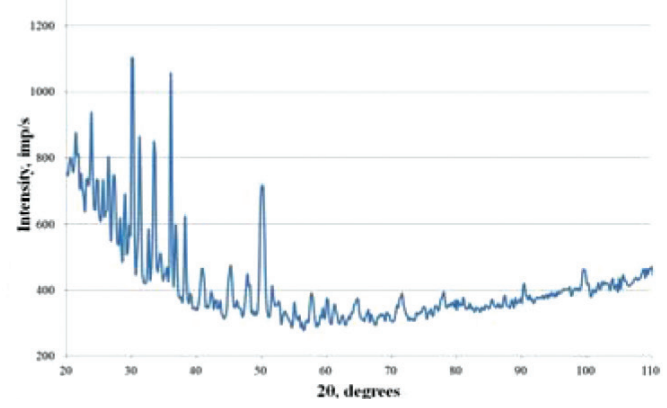

b)

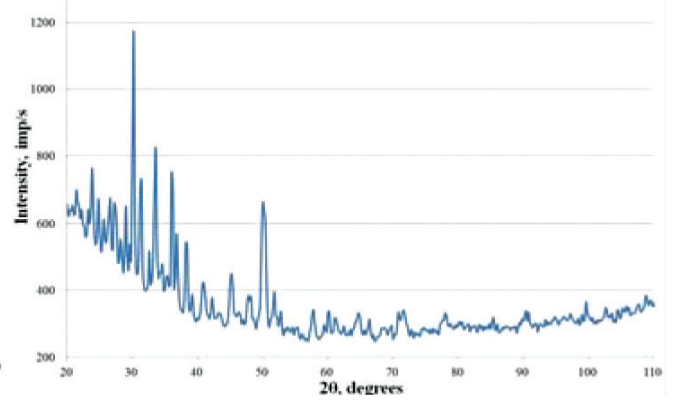

Fig. 3. Diffractogram of the epoxy powder coating with: a) good, b) poor quality of the steel substrate 


\section{Conclusions}

Nowadays, automobile coatings are exposed to many factors. The quality of coatings depends on coating formula, durability of the exterior and interior paint finishes, intensities of the environment and many other factors. Application of coatings is the most widely used corrosion protection method for metallic surfaces. The strength and adhesion of coating depends on the method of preparation and application of the coating. As one of the most important parameters of quality of a coating is its adhesion, particular attention should be paid to the proper development of the surface of a steel substrate and determination of appropriate roughness.

\section{References}

[1] Shirehjini F.T., Danaee I., Eskandari H., Zarei D., Effect of Nano Clay on Corrosion Protection of Zinc-rich Epoxy Coatings on Steel 37, Journal of Materials Science \& Technology, vol. 32(11), 2016, 1152-1160.

[2] Sutar V., Dharankar C.S., Thirupathi Raju B., High Strength Steel for Automotive Applications, International Research Journal of Engineering and Technology, vol. 3(5), 2016, 966-968.

[3] Ranjbarnodeh E., Pouranvari M., Fischer A., Influence of welding parameters on residual stresses in dissimilar HSLA steels welds, Association of Metallurgical Engineers of Serbia, vol. 19(1), 2013, 33-43.

[4] Saha D.C., Westerbaan D., Nayak S.S., Biro E., Gerlich A.P., Zhou Y., Microstructureproperties correlation in fiber laser welding of dual-phase and HSLA steels, Materials Science and Engineering A, vol. 607(23), 2014, 445-453.

[5] Ulewicz R., Novy F., Mazur M., Szataniak P., Fatigue properties of the HSLA steel in high and ultra-high cycle region, Production Engineering Archives, vol. 4(3), 2014, 18-21.

[6] SuayJ.J., Rodriguez M.T., Razzaq K.A., Carpio J.J., Saura J.J., The evaluation of anticorrosive automotive epoxy coatings by means of electrochemical impedance spectroscopy, Progress in Organic Coatings, vol. 46(2), 2003, 121-129.

[7] Akafuah N.K., Poozesh S., Salaimeh A., Patrick G., Lawler K., Saito K., Evolution of the Automotive Body Coating Process - A Review, Coatings, vol. 6(2), 2016, 1-22.

[8] Canosa G., Alfieri P.V., Giudice C.A., High-solids, one-coat paints based on aliphatic epoxy resinsiloxanes for steel protection, Progress in Orgainc Coatings, vol. 77(9), 2014, 1459-1464.

[9] Roselli S.N., Romagnoli R., Deya C., The anti-corrosion performance of water-borne paints in long term tests, Progress in Organic Coatings, vol. 109, 2017, 172-178.

[10] David R., Raja V.S., Singh S.K., Gore P., Development of anti-corrosive paint with improved toughness using carboxyl terminated modified epoxy resin, Progress in Organic Coatings, vol. 120, 2018, 58-70.

[11] Liu S., Chevali V.S., Xu Z., Hui D., Wang H., A review of extending performance of epoxy resins using carbon nanomaterials, Composites Part B: Engineering, vol. 136, 2018, 197-214.

[12] ISO 2409:2013 Paints and varnishes - Cross-cut test, fourth edition. 